\title{
Studies on the occurrence of nutritionally and toxicologically significant metals in selected marine edible fish and their availability in in vitro hydrolysates.
}

$$
\text { by }
$$

Indira Wickramasinghe 
Studies on the occurrence of nutritionally and toxicologically significant metals in selected marine edible fish and their availability in in vitro hydrolysates.

by

Indira Wickramasinghe

Thesis submitted to the University of Sri Jayewardenepura for the award of the Degree of Doctor of Philosophy in Food Science on 2009. 


\section{DECLARATION}

The work described in this thesis was carried out by me under the supervision of Prof. Arthur Bamunuarachchi, Professor of Applied Chemistry, Department of Food Science and Technology, Faculty of Applied Sciences, University of Sri Jayewardenepura and Prof. K.K.D.S. Ranaweera, Head/Department of Food Science and Technology, Faculty of Applied Sciences, University of Sri Jayewardenepura, and a report on this has not been submitted in whole or in part to any university or any other institution for another Degree.

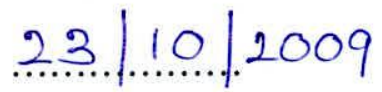

Date

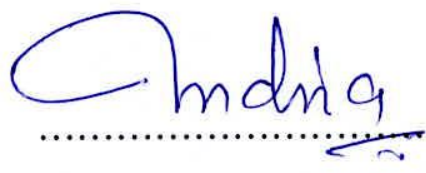

Indira Wickramasinghe 
"We certify that the above statement made by the candidate is true and that this thesis is suitable for submission to the University for the purpose of evaluation".

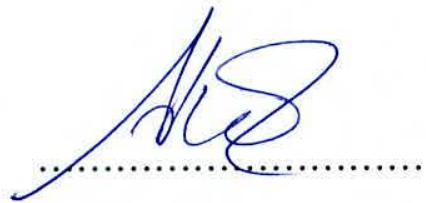

Signature,

Supervisor,

Prof. Arthur Bamunuarachchi,

Professor of Applied Chemistry,

Department of Food Science and Technology,

Faculty of Applied Sciences,

University of Sri Jayewardenepura,

Gangodawila, Nugegoda, Sri Lanka.

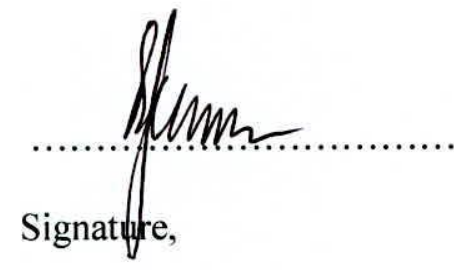

Supervisor,

Prof. K.K.D.S.Ranaweera,

Head / Department of Food Science and Technology,

Faculty of Applied Sciences,

University of Sri Jayewardenepura, Gangodawila, Nugegoda, Sri Lanka. 
We certify that the candidate is submitting this thesis with all corrections, additions and amendments attended in accordance with the comments and suggestions by the examiners.

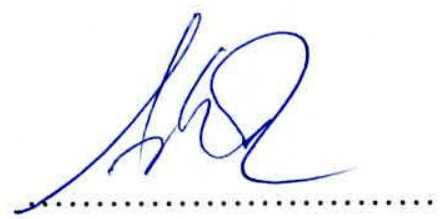

Signature,

Supervisor,

Prof. Arthur Bamunuarachchi,

Professor of Applied Chemistry,

Department of Food Science and Technology,

Faculty of Applied Sciences,

University of Sri Jayewardenepura,

Gangodawila, Nugegoda, Sri Lanka.

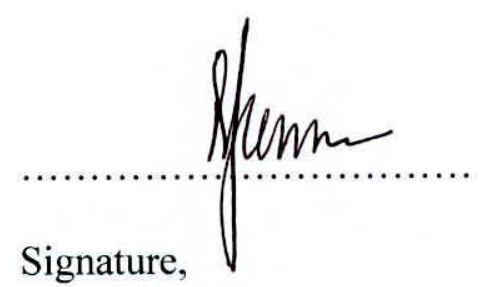

Supervisor,

Prof. K.K.D.S. Ranaweera,

Head / Department of Food Science and Technology,

Faculty of Applied Sciences,

University of Sri Jayewardenepura,

Gangodawila, Nugegoda, Sri Lanka.

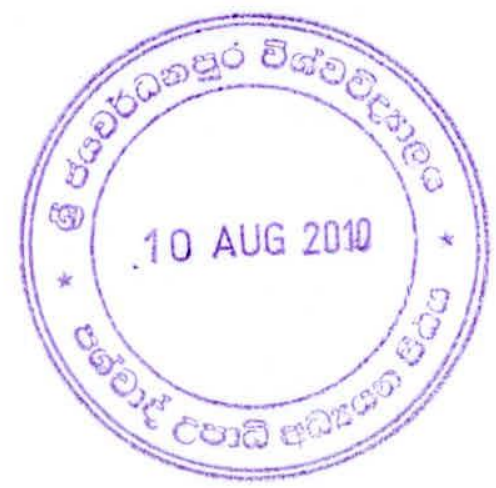




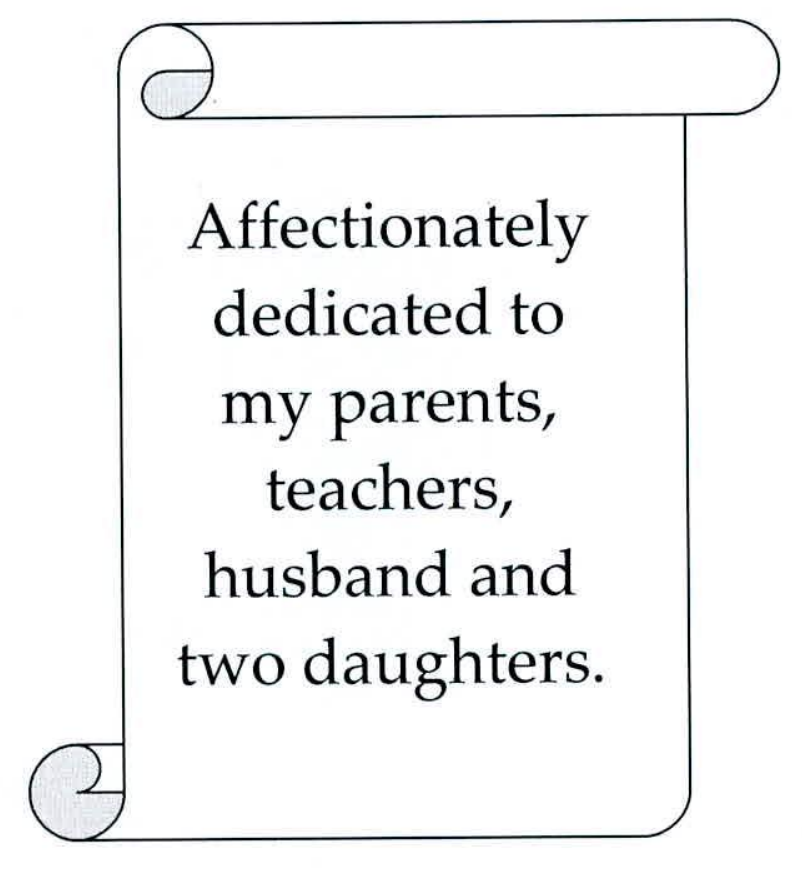




\section{TABLE OF CONTENTS}

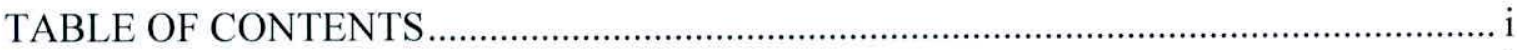

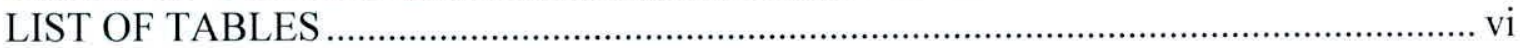

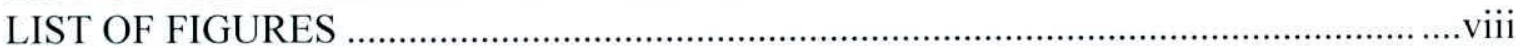

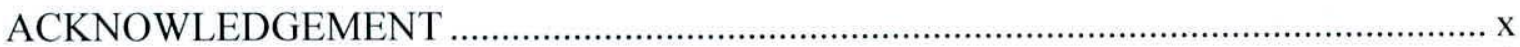

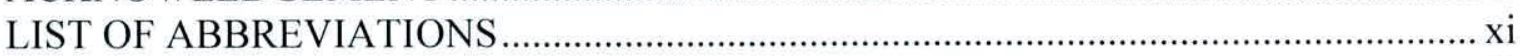

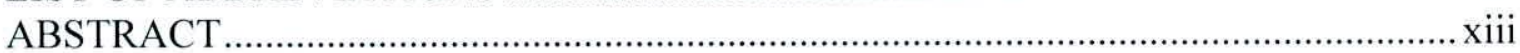

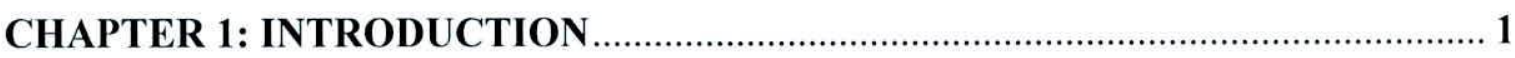

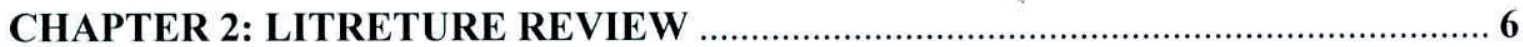

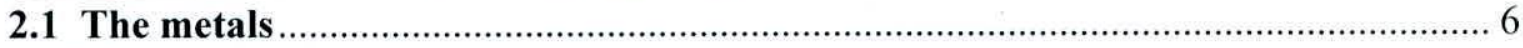

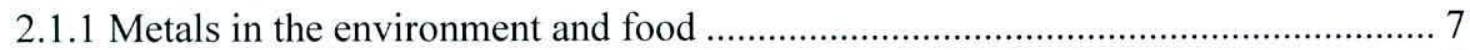

2.1.2 The metal content of the human body.................................................................. 7

2.1.3 The role of metals in the human body............................................................. 8

2.1.3.1 The macro minerals................................................................................ 9

2.1.3.2 The micro minerals ............................................................................. 9

2.1.4 Classification of minerals according to their biological role .............................. 10

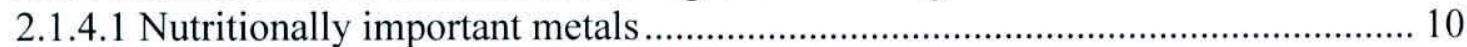

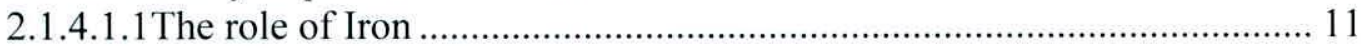

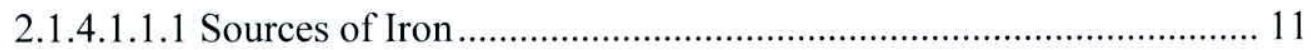

2.1.4.1.1.2 Digestion and absorption of Iron ............................................. 13

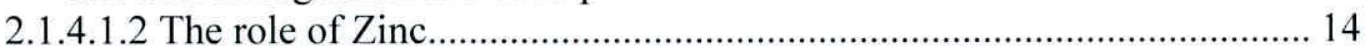

2.1.4.1.2.1 The sources of Zinc...................................................................... 15

2.1.4.1.2.2 The absorption and transport of Zinc ........................................ 15

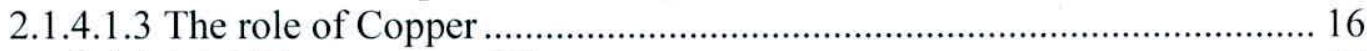

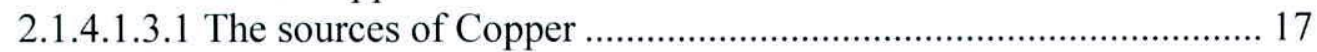

2.1.4.1.3.2 The absorption and transport of Copper ...................................... 17

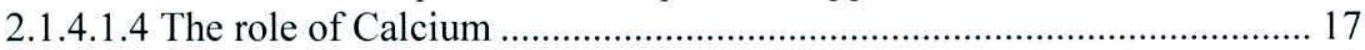

2.1.4.1.4.1 The sources of Calcium.................................................................... 18

2.1.4.1.4.2 Digestion absorption and transport of Calcium ........................... 18

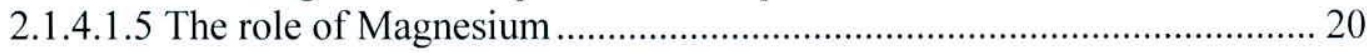

2.1.4.1.5.1 The sources of Magnesium ........................................................ 20

2.1.4.1.5.2 Absorption and transport of Magnesium ................................... 20

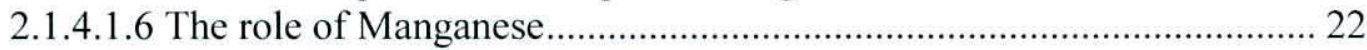

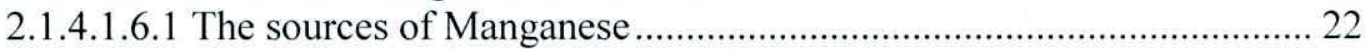

2.1.4.1.6.2 The absorption, transport and storage of Manganese .................. 22

2.1.4.1.6.3 Functions and mechanisms of action of Manganese..................... 24

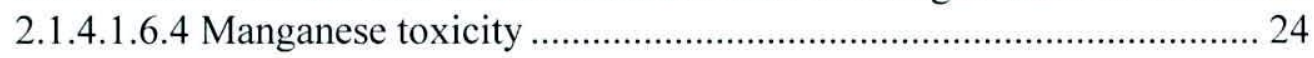

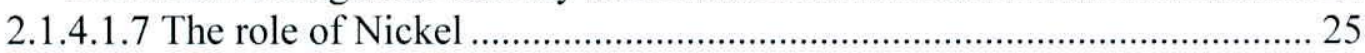

2.1.4.1.7.1 The souces of Nickel.................................................................... 25

2.1.4.1.7.2 The absorption, transport and storage of Nickel ........................ 25

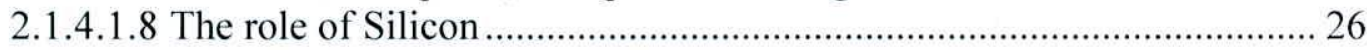

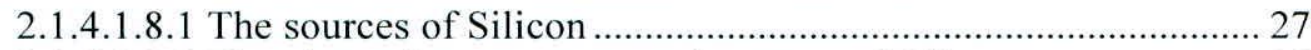

2.1.4.1.8.2 The absorption, transport and storage of Silicon ...................... 27 


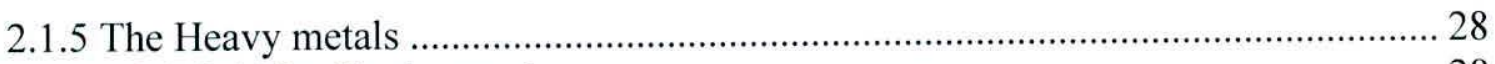

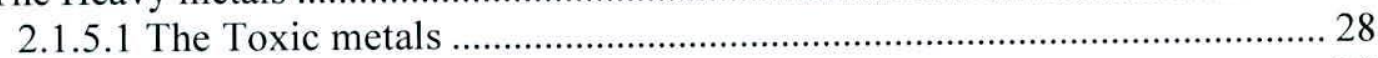

2.1.5.2 The occurrence and Toxicity of Lead ................................................. 30

2.1.5.2.1 The sources of Lead ......................................................................... 30

2.1.5.2.2 The permissible level of Lead ....................................................... 31

2.1.5.2.3 The absorption of Lead............................................................... 31

2.1.5.3 The occurrence and toxicity of Cadmium ........................................... 32

2.1.5.3.1 The permissible level of Cadmium .............................................. 33

2.1.5.3.2 The absorption of Cadmium to body …........................................ 33

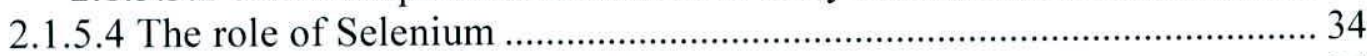

2.1.5.4.1 The dietary intake of Selenium .................................................. 34

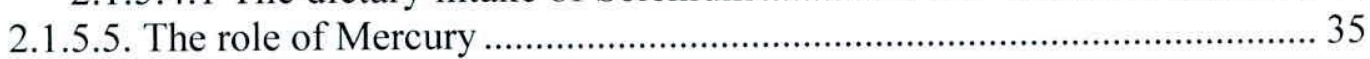

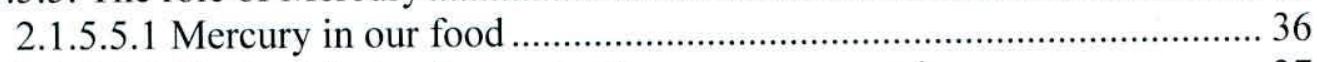

2.1.5.5.2 Toxic effects of organic Mercury compounds ............................ 37

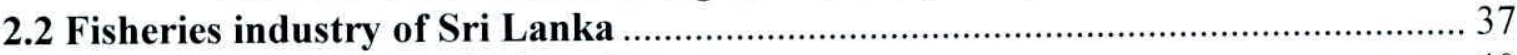

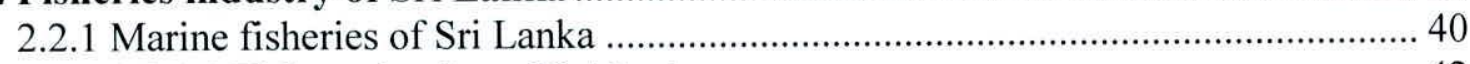

2.2.1.1 Fish production of Sri Lanka .............................................................. 42

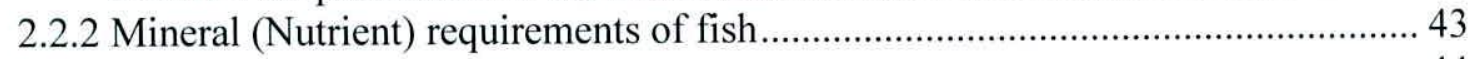

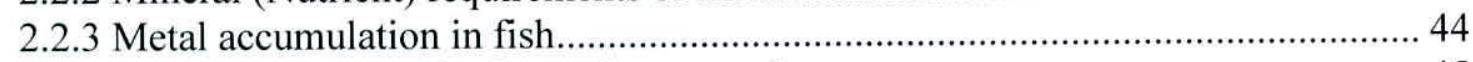

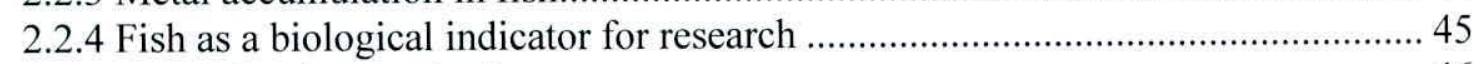

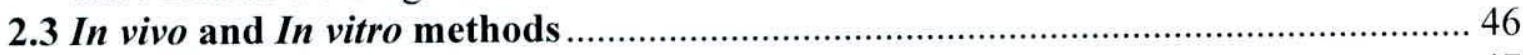

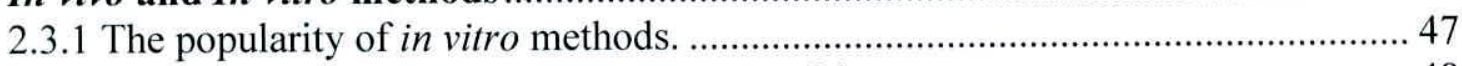

2.3.1.1 Simulation of gastro intestinal conditions........................................... 48

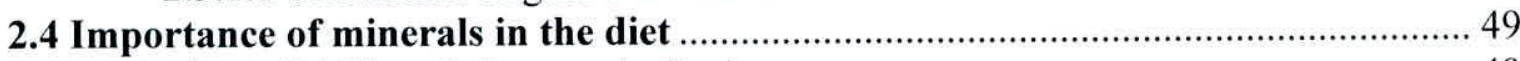

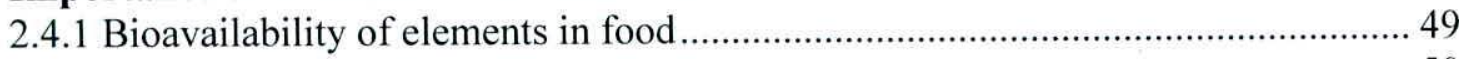

2.4.1.1 Factors influencing the bioavailability................................................. 50

2.4.2 The effect of cooking of fish on its nutrient composition.................................. 50

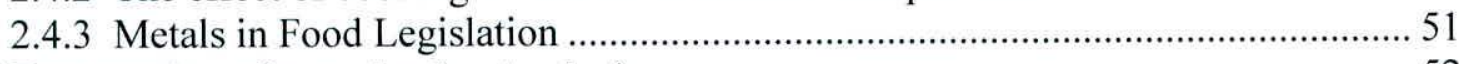

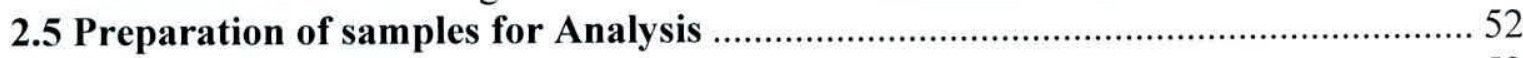

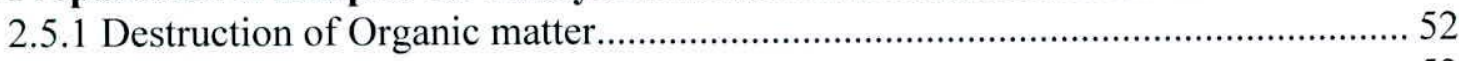

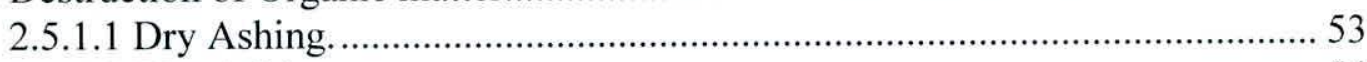

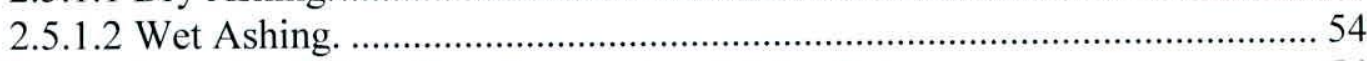

2.5.2 Preparation of solutions for subsequent metal Analysis .................................. 54

2.5.3 End determination methods of metal analysis .................................................... 55

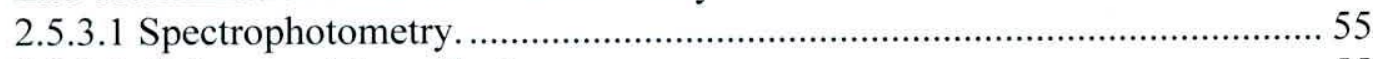

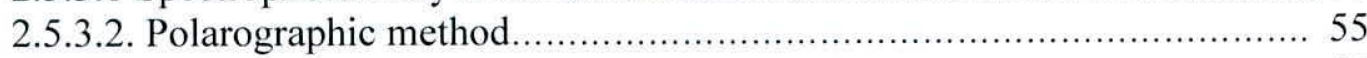

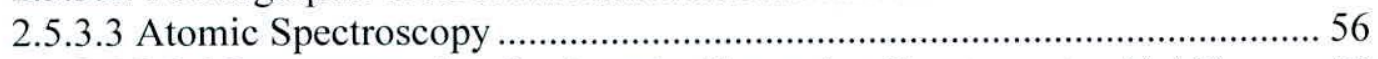

2.5.3.3.1 Instrumentation for Atomis Absorption Spectrometry (AAS)......... 58

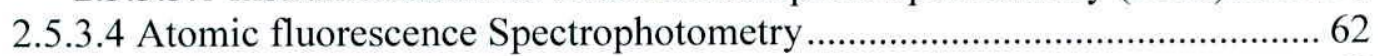

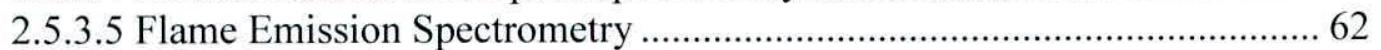

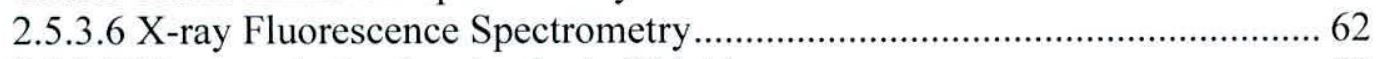

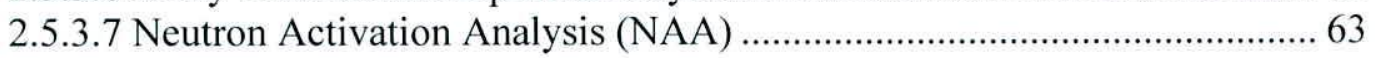

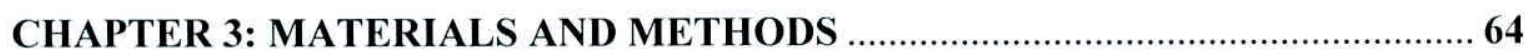

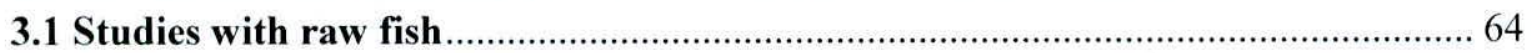

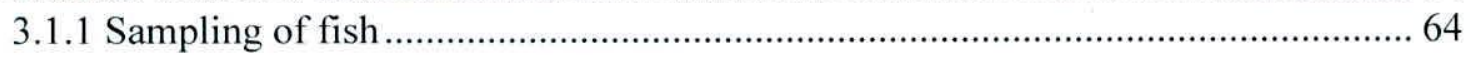




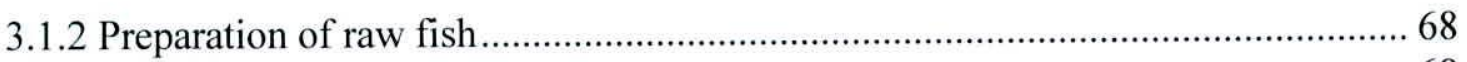

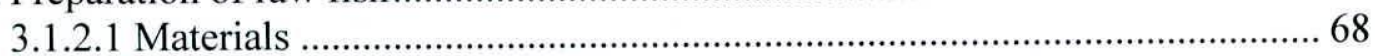

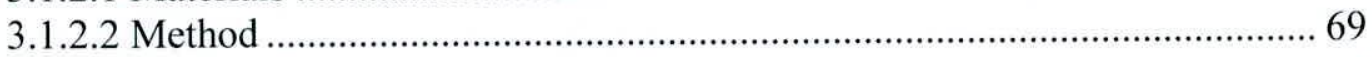

3.1.3 Determination of moisture content of fish ....................................................... 71

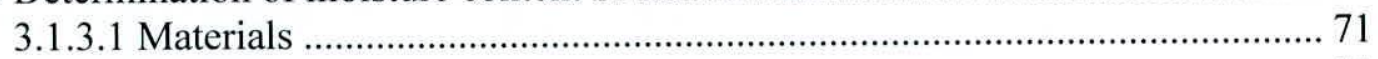

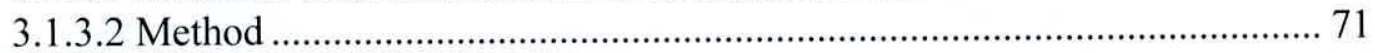

3.1.4 Determination of Ash content of fish............................................................... 72

3.1.4.1 Materials ............................................................................................ 72

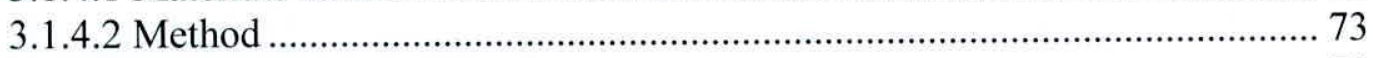

3.1.5 Preparation of raw fish hydrolysates.............................................................. 75

3.1.5.1 Materials ......................................................................................... 75

3.1.5.2 Method .................................................................................................... 77

3.1.5.2.1Preparation of chemical solutions for the fish hydrolysates............. 79

3.1.5.2.2 Preparation of buffer solution for the fish hydrolysates .................. 79

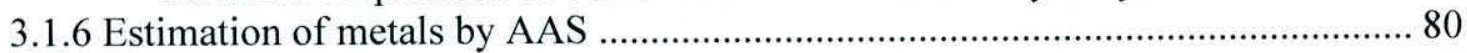

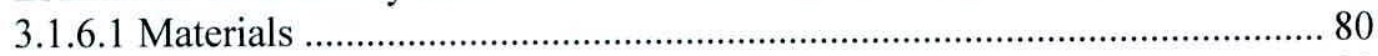

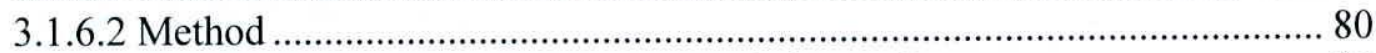

3.1.6.2.1 Preparation of element standards for AAS .................................... 82

3.1.6.2.2 Preparation of working solutions for AAS .................................... 82

3.1.6.2.3 Construction of Calibration plots.................................................... 82

3.1.6.2.4 Determination of metal content infish sample using AAS .............. 83

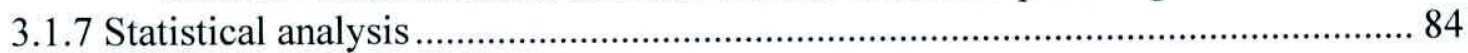

3.1.8 Estimation of metals by X-ray fluorescence Analysis .......................................... 85

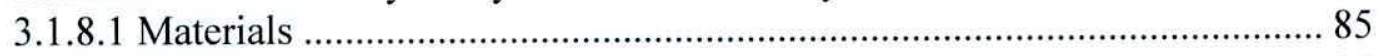

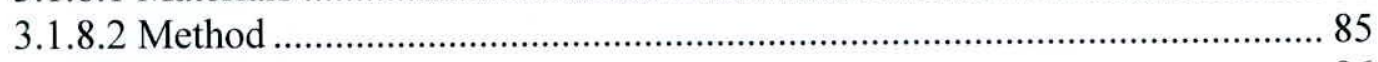

3.1.8.2.1 Accuracy test............................................................................. 86

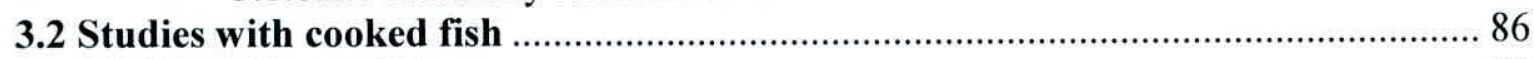

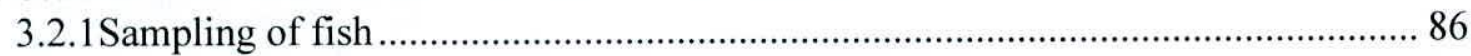

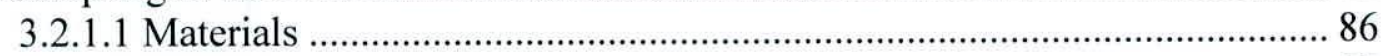

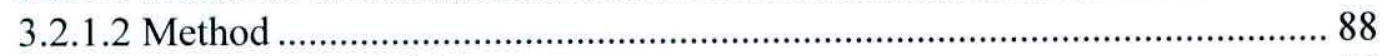

3.2.2 Preparation of cooked fish ............................................................................ 89

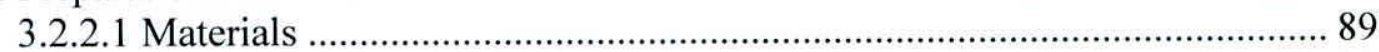

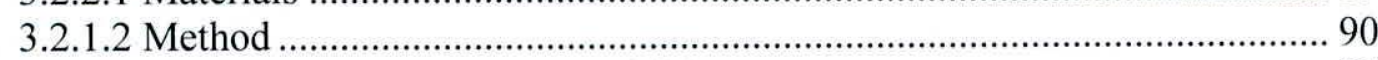

3.2.3 Determination of moisture content of fish ........................................................... 91

3.2.3.1 Materials ............................................................................................ 91

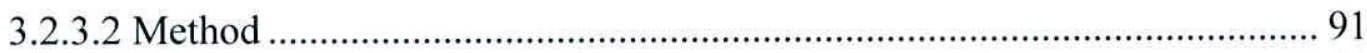

3.2.4 Determination of Ash content of fish................................................................ 91

3.2.4.1 Materials .......................................................................................... 91

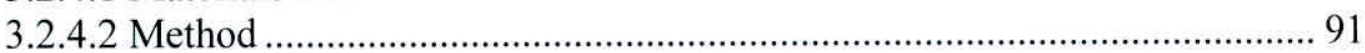

3.2.5 Preparation of cooked fish hydrolysates ................................................................ 91

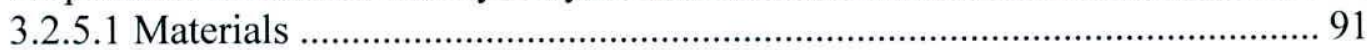

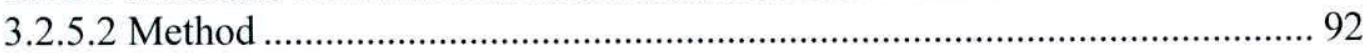

3.2.6 Estimation of metals by AAS ……………………...................................... 92

3.2.6.1 Materials ........................................................................................... 92

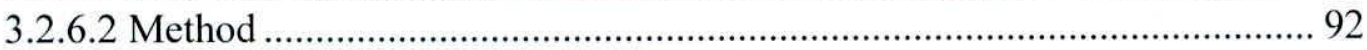

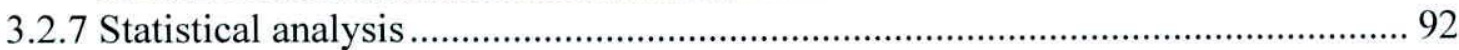




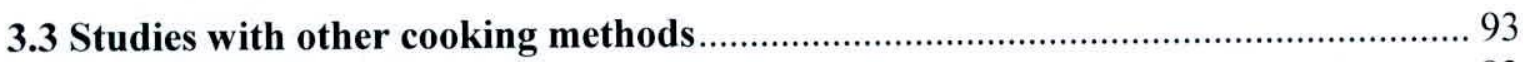

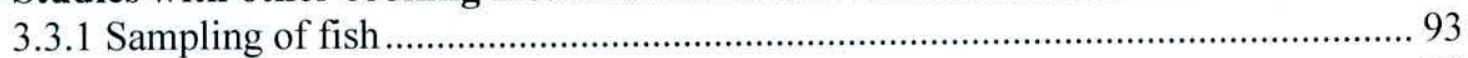

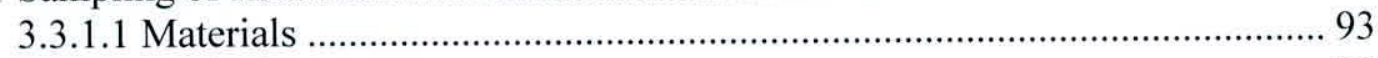

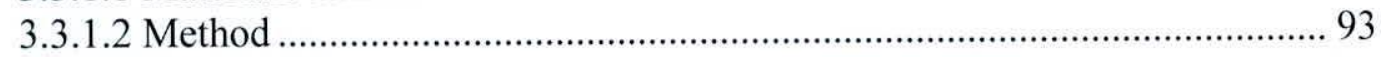

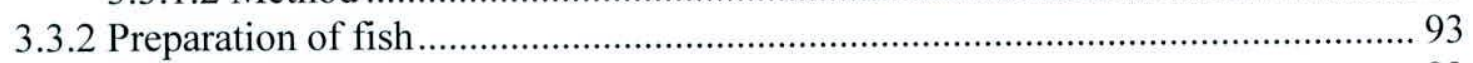

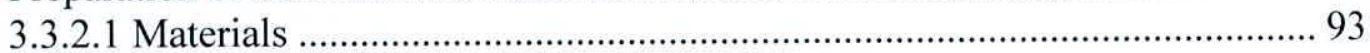

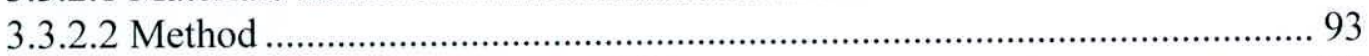

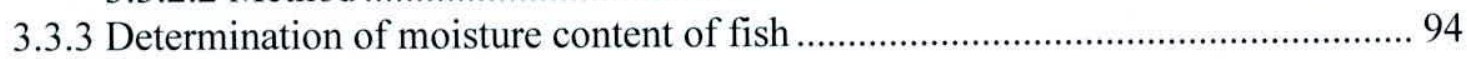

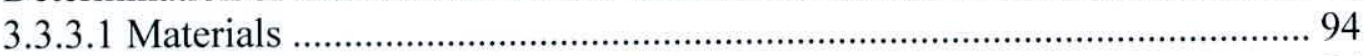

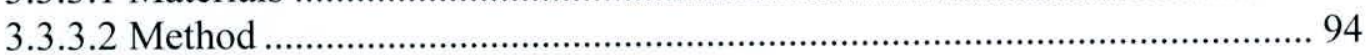

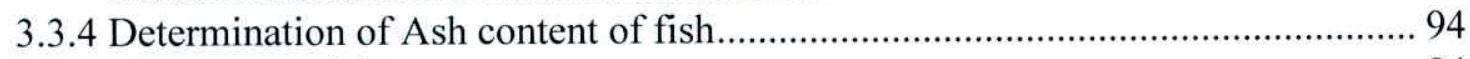

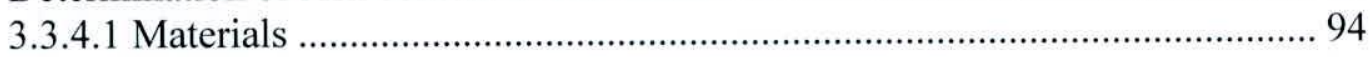

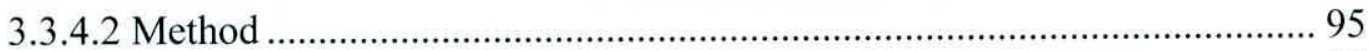

3.3.5 Preparation of raw and cooked fish hydrolysates ............................................... 95

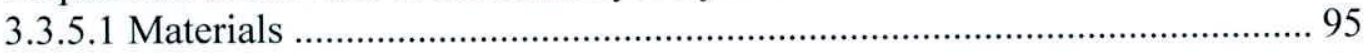

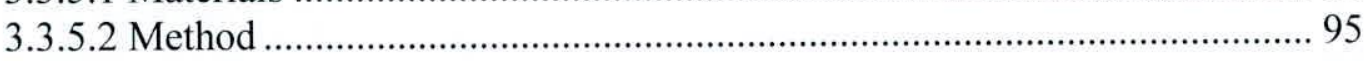

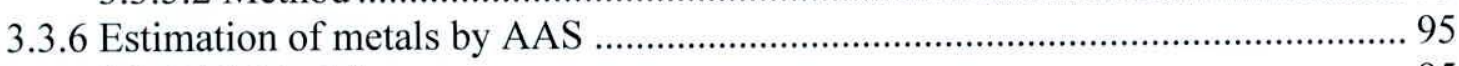

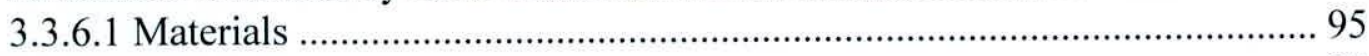

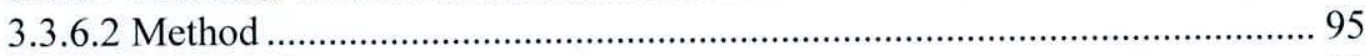

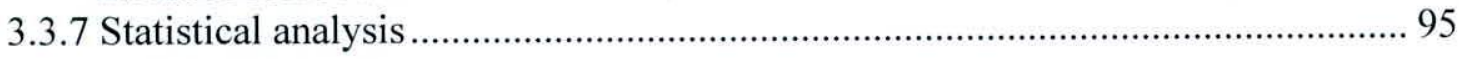

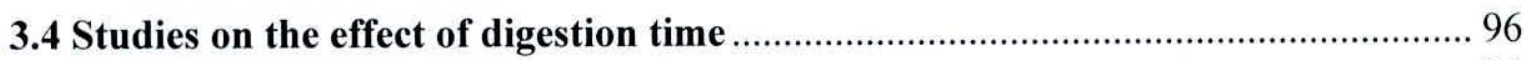

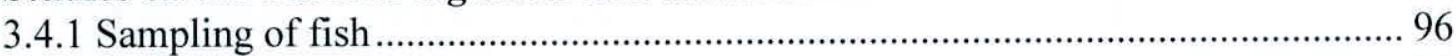

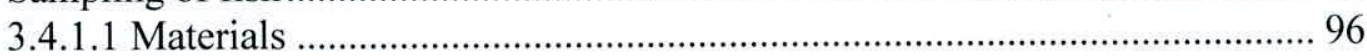

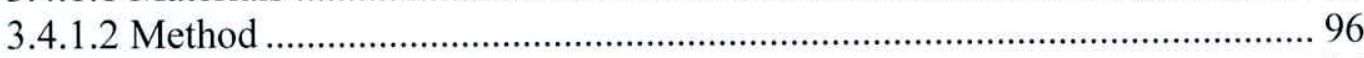

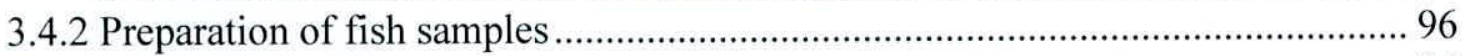

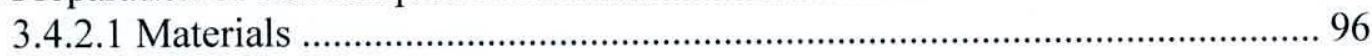

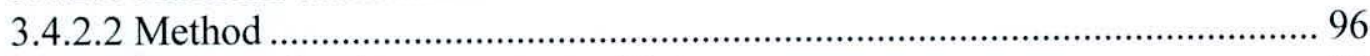

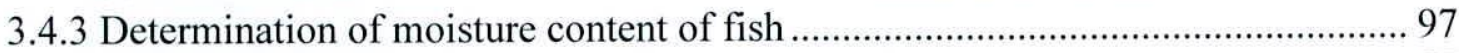

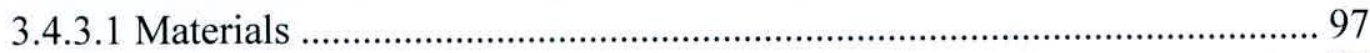

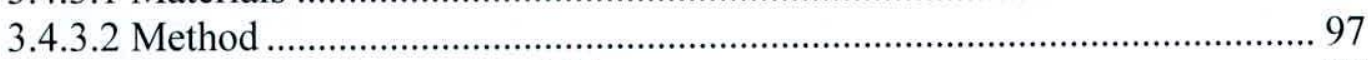

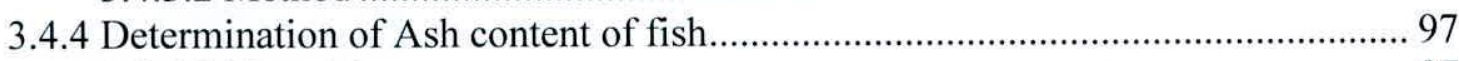

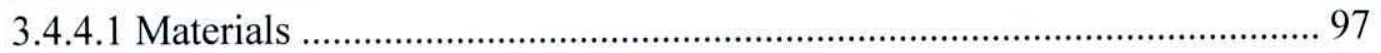

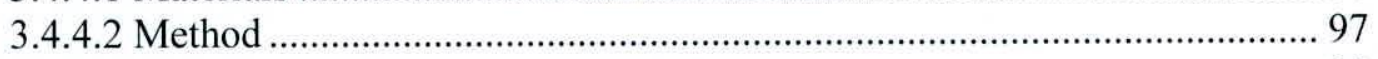

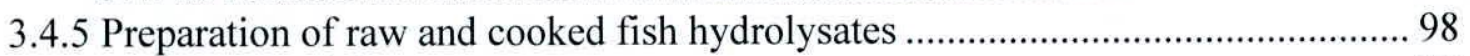

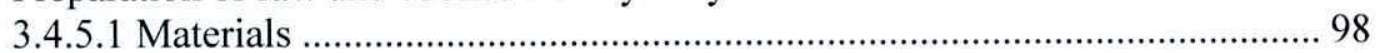

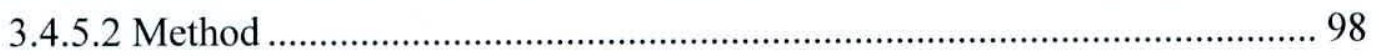

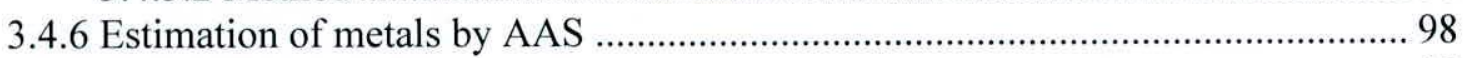

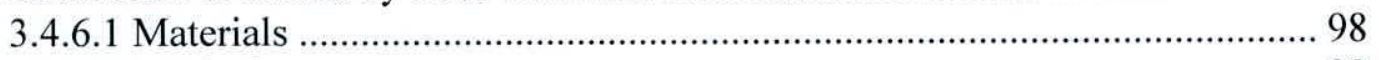

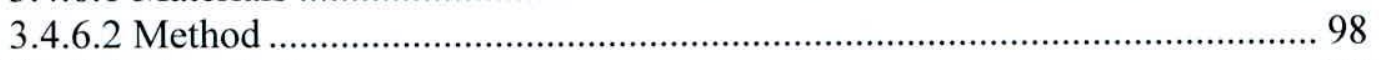

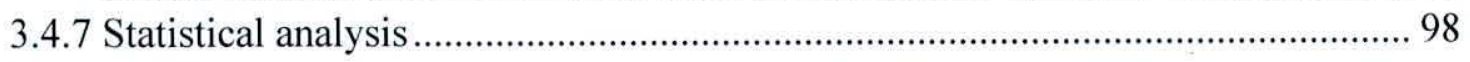

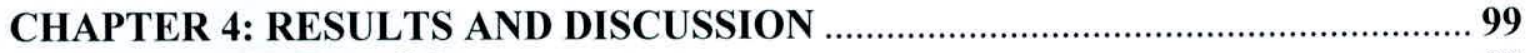

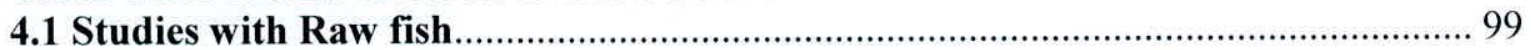

4.1.1 Estimation of metals by Atomic Absorption Spectrometry (AAS) ...................... 99

4.1.1.1 Estimation of metals in raw fish hydrolysates .................................... 114 
4.1.2 Estimation of metals by X-ray fluorescence Analysis

4.2 Studies with cooked fish

4.2.1 Estimation of metals by AAS in S. melanura, S. albella E. volitans and in

Carnax spp.

4.2.2 Estimation of metals by AAS in Stolephorus commersoni, Anchovy

commersonii, Selar spp and Leiognathus spp.

4.3 Studies with other cooking methods.

4.3.1 Estimation of metals by AAS in the first set of Sardinella melanura

4.3.2 Estimation of metals by AAS in the second set of Sardinella melanura. 165

4.3.3 Estimation of metals by AAS in Amblygaster spp.

4.4 Studies with different in vitro digestion time intervals 191

CHAPTER 5: CONCLUSION 205

REFERENCES 213

APPENDICES i - xxvii 


\section{LIST OF TABLES}

Table 2.1: Recommended Dietary Allowances (RDA) and Adequate Intake (AI) for minerals

Table 2.2: Substances/Nutrients affecting Intestinal absorption or interacting with

Magnesuim at an extraintestinal site

Table 2.3: The Selenium consumption ( $\mu \mathrm{g} /$ day) in different parts of the world

Table 2.4: Sri Lankan Fish production compared with selected Asian countries different parts of the world

Table 2.5: Important indicators to evaluate the fisheries sector of Sri Lanka .................... 41

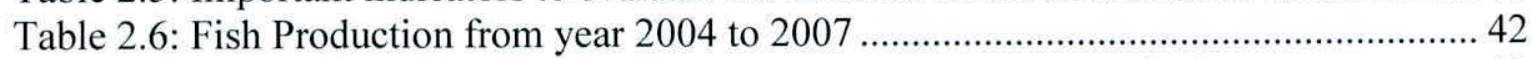

Table 2.7: Permissible upper limits of trace elements in various standards ....................... 52

Table 3.1.6.1: The recommended working conditions for element analysis in AAS .......... 81

Table 4.1.1.1: Moisture and Ash contents of fish species ............................................... 100

Table 4.1.1.2: The micro metal content of fish species $\{\mu \mathrm{g} / \mathrm{g}$, dry weight (DW) ............. 101

Table 4.1.1.3: The nutritionally important macro metals of fish species

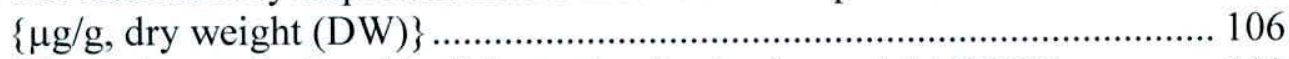

Table 4.1.1.4: The toxic metals found in fish species $\{\mu \mathrm{g} / \mathrm{g}$, dry weight (DW) $\} \ldots \ldots \ldots \ldots . . . .110$

Table 4.1.1.5: The in vitro available $\mathrm{Fe}, \mathrm{Zn}, \mathrm{Cu}$ and $\mathrm{Pb}$ content of raw fish

hydrolysates ................................................................................... 114

Table 4.1.2.1: The nutritionally important micro metal content of fish species ................ 118

Table 4.1.2.2: The macro metal and mineral content of fish species.................................. 121

Table 4.1.2.3: The micro and toxic metal content of fish species..................................... 125

Table 4.2.1.1: The Iron content in cooked fish flesh, fish bones cooking water medium and the in vitro available iron content ...................................... 128

Table 4.2.2.1: Moisture and ash contents of raw and cooked fish species ......................... 134

Table 4.2.2.2: The mean iron content of raw and cooked fish flesh, fish bones, cooking water medium and the in vitro available iron content of cooked fish with percentages......................................................................................... 136

Table 4.3.1.1: Moisture and ash contents of raw, dried and cooked Sardinella melanura 146

Table 4.3.1.2: The Fe contents of raw, dried and cooked Sardinella melanura ............... 147

Table 4.3.1.3: The Zn contents of raw and cooked Sardinella melanura .......................... 150

Table 4.3.1.4: The $\mathrm{Cu}$ contents of raw and cooked Sardinella melanura ........................... 153

Table 4.3.1.5: The Mg contents of raw and cooked Sardinella melanura ......................... 156

Table 4.3.1.6: The Na contents of raw and cooked Sardinella melanura.......................... 159

Table 4.3.1.7: The Pb contents of raw and cooked Sardinella melanura ......................... 162

Table 4.3.2.1: Moisture and ash contents of raw, dried and cooked Sardinella melanura 165

Table 4.3.2.2: The Fe contents of raw and cooked Sardinella melanura ......................... 166

Table 4.3.2.3: The Zn contents of raw and cooked Sardinella melanura .......................... 169

Table 4.3.2.4: The $\mathrm{Cu}$ contents of raw and cooked Sardinella melanura ........................... 172

Table 4.3.2.5: The Pb contents of raw and cooked Sardinella melanura ........................... 174

Table 4.3.3.1: Moisture and ash contents of raw, dried and cooked Amblygaster spp. ... 178

Table 4.3.3.2: The Fe contents of raw and cooked Amblygaster spp. .............................. 179

Table 4.3.3.3: The Zn contents of raw and cooked Amblygaster spp.............................. 182 
Table 4.3.3.4: The Cu contents of raw and cooked Amblygaster spp

Table 4.3.3.5: The Pb contents of raw, dried and cooked Amblygaster spp.

Table 4.4.1: Moisture and ash contents of raw and cooked Sardinella melanura and Amblygaster spp.

Table 4.4.2: The in vitro and in vitro remainings Fe content of cooked S. melanura and Amblygaster spp. with different digestion time intervals

Table 4.4.3: The in vitro and in vitro remainings $\mathrm{Zn}$ content of cooked $S$. melanura and Amblygaster spp. with different digestion time intervals

Table 4.4.4: The in vitro and in vitro remainings $\mathrm{Cu}$ content of cooked $S$. melanura and Amblygaster spp. with different digestion time intervals ....

Table 4.4.5: The in vitro and in vitro remainings $\mathrm{Pb}$ content of cooked $S$. melanura and Amblygaster spp. with different digestion time intervals 


\section{LIST OF FIGURES}

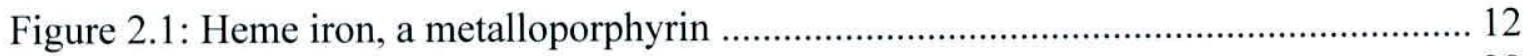

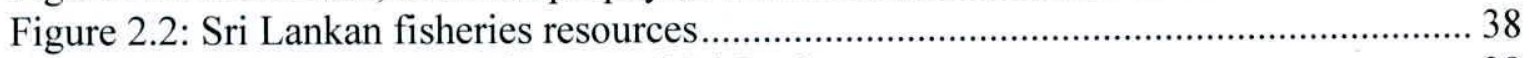

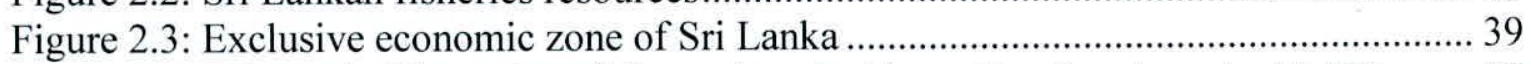

Figure 2.4: Schematic illustration of flame Atomic Absorption Spectrometry(AAS) ........ 58

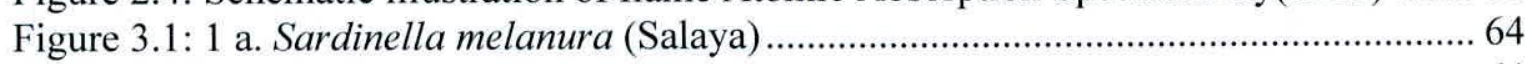

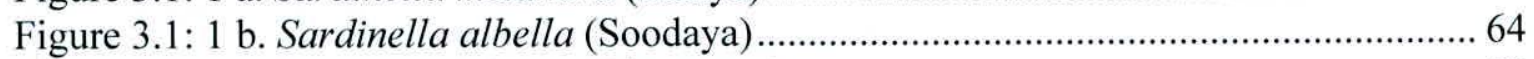

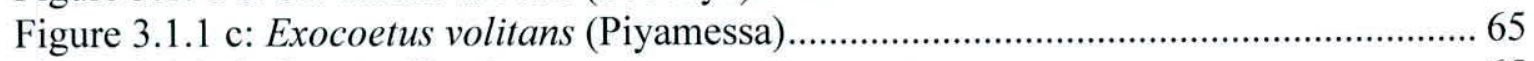

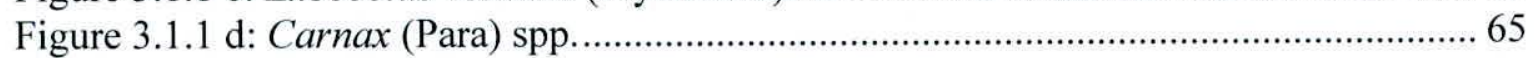

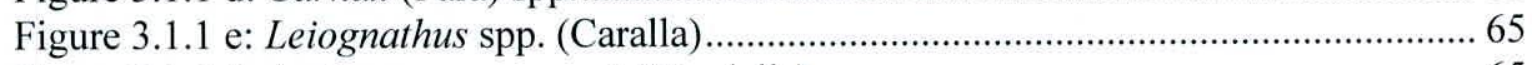

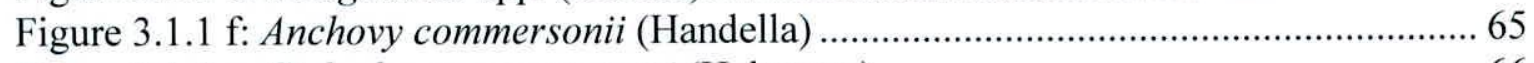

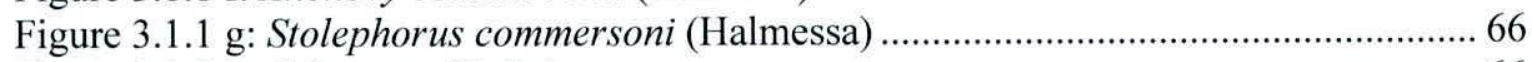

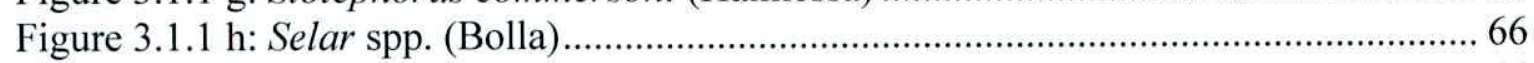

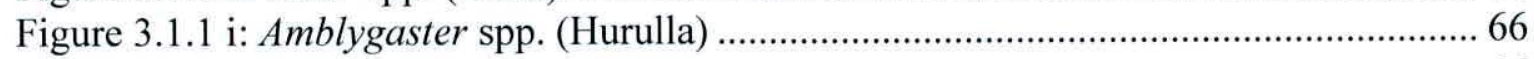

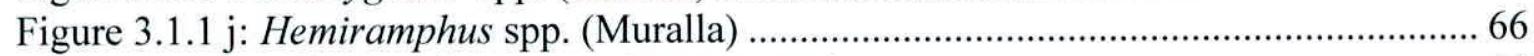

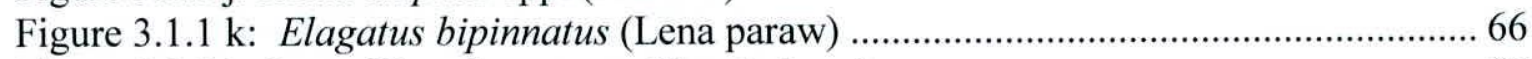

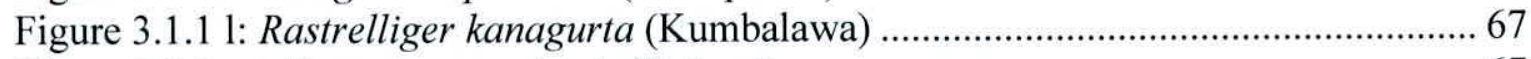

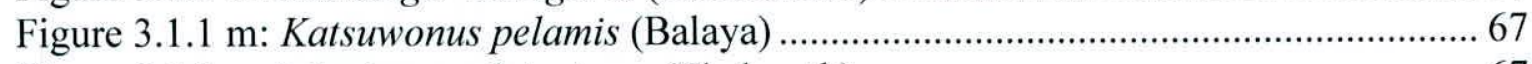

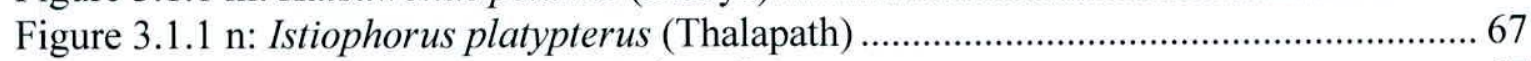

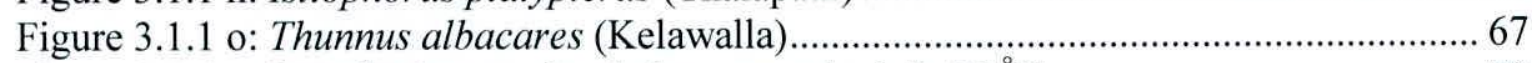

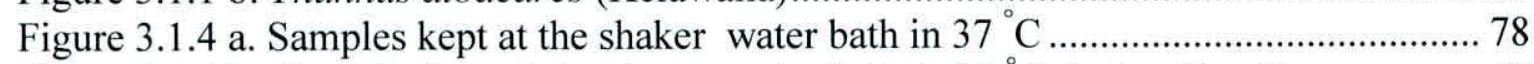

Figure 3.1 .4 b. Samples kept at the shaker water bath in $37^{\circ} \mathrm{C}$ during digestion............... 78

Figure $3.1 .4 \mathrm{c}$ : A schematic illustration of in vitro digestion method ................................. 78

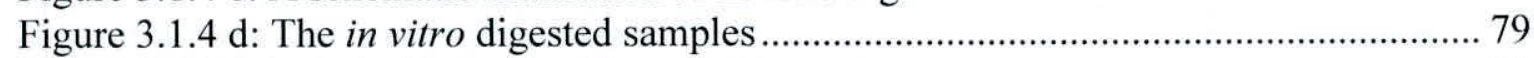

Figure 3.1.6.1 Atomic Absorption Spectrophotometer .................................................. 81

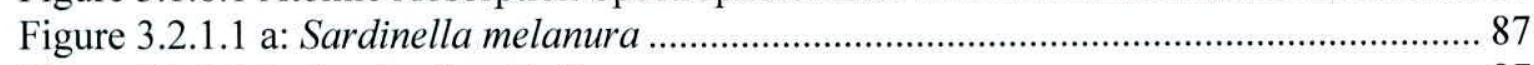

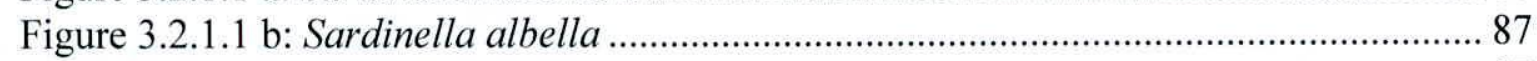

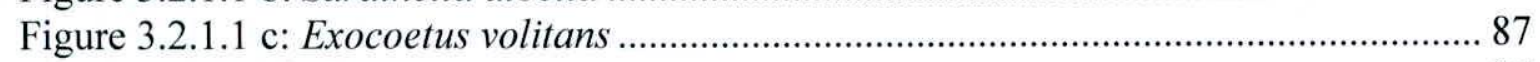

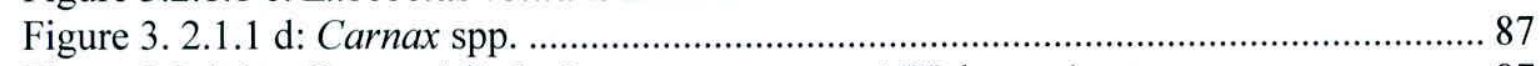

Figure 3.2.1.1 e: Grouped Stolephorous commersoni (Halmessa) .................................... 87

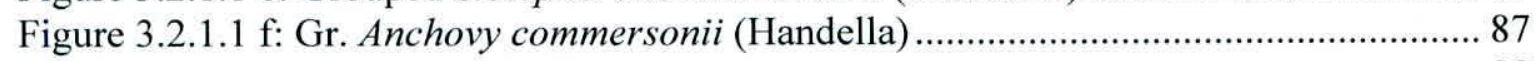

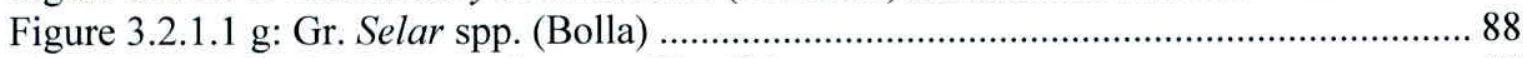

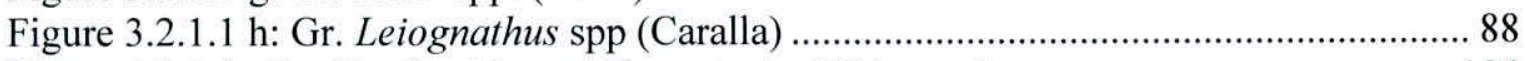

Figure 4.1.1.1: $\mathrm{Fe}, \mathrm{Zn}, \mathrm{Cu}, \mathrm{Mn}$ and $\mathrm{Cr}$ content of fish species ...................................... 104

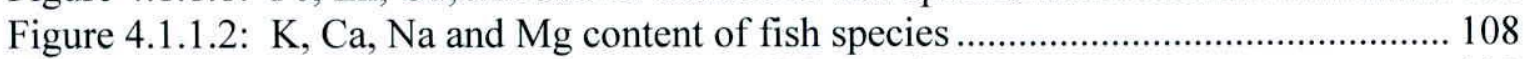

Figure 4.1.1.3: The $\mathrm{Pb}, \mathrm{Ni}$, and $\mathrm{Cd}$ content of fish species ............................................ 113

Figure 4.1.1.4: The in vitro available $\mathrm{Fe}, \mathrm{Zn}, \mathrm{Cu}$ and $\mathrm{Pb}$ content of raw fish

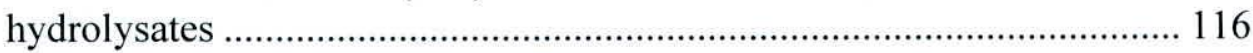

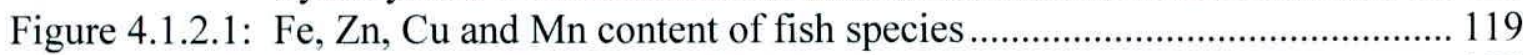

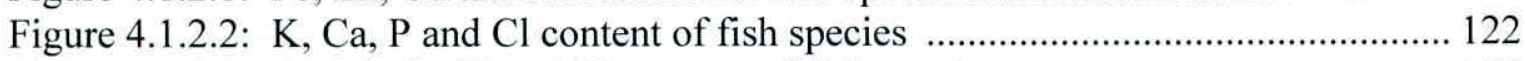

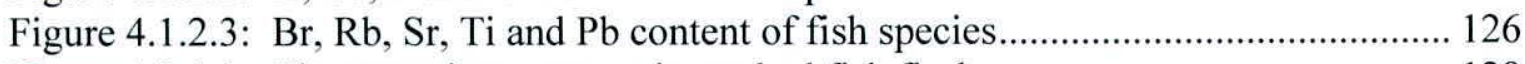

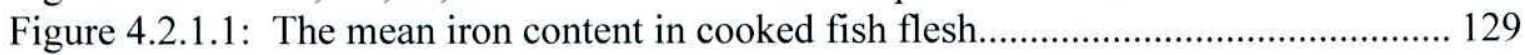

Figure 4.2.1.2: The mean iron content in cooked fish bones ......................................... 130

Figure 4.2.1.3: The mean iron content retained in cooking water medium ...................... 131 
Figure 4.2.1.4: The total in vitro available iron content of fish ................................... 132

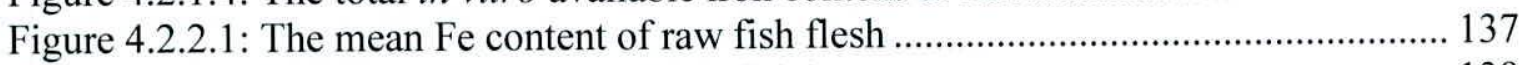

Figure 4.2.2.2: The mean Fe content of raw fish bones.................................................. 139

Figure 4.2.2.3: The iron content of cooked fish flesh ..................................................... 140

Figure 4.2.2.4: The iron content of cooked fish bones ................................................... 142

Figure 4.2.2.5: The mean iron content of cooking water medium .................................... 143

Figure 4.2.2.6: In vitro available iron content............................................................... 144

Figure 4.3.1.1: The Fe content, in vitro available Fe content and in vitro remainings

Fe content of raw and cooked $S$. melanura ........................................... 149

Figure 4.3.1.2: The $\mathrm{Zn}$ content, in vitro available $\mathrm{Zn}$ content and in vitro remainings $\mathrm{Zn}$ content of raw and cooked $S$. melanura ........................................... 152

Figure 4.3.1.3: The $\mathrm{Cu}$ content, in vitro available $\mathrm{Cu}$ content and in vitro remainings $\mathrm{Cu}$ content of raw and cooked $S$. melanura ............................................ 155

Figure 4.3.1.4: The $\mathrm{Mg}$ content, in vitro available $\mathrm{Mg}$ content and in vitro remainings $\mathrm{Mg}$ content of raw and cooked $S$. melanura ....................................... 158

Figure 4.3.1.5: The Na content, in vitro available $\mathrm{Na}$ content and in vitro remainings $\mathrm{Na}$ content of raw and cooked $S$. melanura .............................................. 161

Figure 4.3.1.6: The $\mathrm{Pb}$ content, in vitro available $\mathrm{Pb}$ content and in vitro remainings $\mathrm{Pb}$ content of raw and cooked $S$. melanura........................................... 164

Figure 4.3.2.1: The Fe content, in vitro available Fe content and in vitro remainings Fe content of raw and cooked $S$. melanura.

Figure 4.3.2.2: The $\mathrm{Zn}$ content, in vitro available $\mathrm{Zn}$ content and in vitro remainings $\mathrm{Zn}$ content of raw and cooked $S$. melanura

Figure 4.3.2.3: The $\mathrm{Cu}$ content, in vitro available $\mathrm{Cu}$ content and in vitro remainings $\mathrm{Cu}$ content of raw and cooked $S$. melanura

Figure 4.3.2 4: The $\mathrm{Pb}$ content, in vitro available $\mathrm{Pb}$ content and in vitro remainings $\mathrm{Pb}$ content of raw and cooked $S$. melanura.

Figure 4.3.3.1: The Fe content, in vitro available Fe content and in vitro remainings Fe content of raw and cooked Amblygaster spp.

Figure 4.3.3.2: The $\mathrm{Zn}$ content, in vitro available $\mathrm{Zn}$ content and in vitro remainings Zn content of raw and cooked Amblygaster spp.

Figure 4.3.3.3: The $\mathrm{Cu}$ content, in vitro available $\mathrm{Cu}$ content and in vitro remainings $\mathrm{Cu}$ content of raw and cooked Amblygaster spp.

Figure 4.3.3.4: The $\mathrm{Pb}$ content, in vitro available $\mathrm{Pb}$ content and in vitro remainings $\mathrm{Pb}$ content of raw and cooked Amblygaster spp.

Figure 4.4.1: The in vitro available Fe content and in vitro remainings Fe content of cooked S. melanura and Amblygaster spp with different digestion time intervals.

Figure 4.4.2: The in vitro available $\mathrm{Zn}$ content and in vitro remainings $\mathrm{Zn}$ content of cooked S. melanura and Amblygaster spp with different digestion time intervals.

Figure 4.4.3: The in vitro available $\mathrm{Cu}$ content and in vitro remainings $\mathrm{Cu}$ content of cooked $S$. melanura and Amblygaster spp with different digestion time intervals

Figure 4.4.4: The in vitro available $\mathrm{Pb}$ content and in vitro remainings $\mathrm{Pb}$ content of S. melanura and Amblygaster spp with different digestion time intervals 


\section{ACKNOWLEDGEMENT}

First and foremost I wish to express my deepest gratitude to my internal supervisors, Prof. Arthur Bamunuarachchi, Professor of Applied Chemistry, Department of Food Science and Technology, Faculty of Applied Sciences, University of Sri Jayewardenepura and Prof. K.K.D.S. Ranaweera, Head, Department of Food Science and Technology, Faculty of Applied Sciences, University of Sri Jayewardenepura for their valuable advice, patience, encouragement and guidance throughout this study and for reading the manuscript and sparing their valuable time in bringing this study to a successful completion.

I wish to express my sincere thanks to Dr. U.G.Chandrika, Senior Lecturer, Department of Biochemistry, Faculty of Medical Sciences, University of Sri Jayewardenepura for her valuable guidance and support during the study period.

Thanks also extended to Dr. H. S. Amarasekara, Head, Department of Forestry and Environmental Science for providing me the opportunity to carry out the analysis using Atomic Absorption Spectrometer. Furthermore I highly appreciate the endless support and assistance given to me by Mr. I. D. Wijesinghe, Technical officer of Forestry and Environmental Science, University of Sri Jayewardenepura, to use the Atomic Absorption Spectrometer.

Also I would like to thank all the academic and non academic staff members of the Department of Food Science and Technology, University of Sri Jayewardenepura for their kind assistance and support throughout this study.

It was the moral support from my family that gave me courage to work hard to complete this report successfully; hence I express my heartfelt thanks to my loving husband Sudath and to my daughters Shani and Sanduni. 


\section{LIST OF ABBREVIATIONS}

PTWI - Provisional tolerable weekly intake

AAS- Atomic Absorption Spectrometry

X-RF - X-ray fluorescence spectrometry

DW - dry weight

$\mu \mathrm{g} / \mathrm{g}-$ micrograms per gram (ppm)

AED - Atomic Emission Detector

ANOVA - Analysis of variance

PTDI - Provisional tolerable daily intake

ATSDR - Agency for Toxic substances and Disease Registry

AOAC - Official methods of Analysis of Association of Official Analytical Chemists

FAO - Food and Agricultural Organization

WHO - World Health Organization

USEPA - United States Environmental Protection Agency

EC - European Communities

Fe - Iron

$\mathrm{Zn}-\mathrm{Zinc}$

K - Potassium

$\mathrm{Cu}$ - Copper

Mg - Magnesium

Ca - Calcium

$\mathrm{Cl}$ - Chloride

$\mathrm{Cr}$ - Chromium 
Mn - Manganese

$\mathrm{Br}$ - Bromine

$\mathrm{Rb}$ - Rubidium

$\mathrm{Sr}$ - Strontium

$\mathrm{Br}$ - Bromine

$\mathrm{Rb}$-Rubidium

$\mathrm{Sr}$ - Strontium

Ti - Titanium

Cd - Cadmium

Hg - Mercury

As - Arsenic

$\mathrm{Pb}$ - Lead

Ni - Nickel 


\title{
Studies on the occurrence of nutritionally and toxicologically significant metals in selected marine edible fish and their availability in in vitro hydrolysates.
}

\section{Indira Wickramasinghe}

\begin{abstract}
Fish is considered to be a rich source of minerals as well as proteins. Fifteen (15) popular fish species were used to study the nutritionally and toxicologically significant metals by using Atomic Absorption Spectroscopy (AAS) and X-ray fluorescence techniques (XRF). In raw fish, $\mathrm{Fe}, \mathrm{Zn}, \mathrm{Cu}, \mathrm{Br}, \mathrm{Mn}, \mathrm{Cr}, \mathrm{K}, \mathrm{Ca}, \mathrm{Na}, \mathrm{Mg}, \mathrm{Cl}, \mathrm{Rb}, \mathrm{Sr}, \mathrm{Ti}, \mathrm{Ni}, \mathrm{Hg}, \mathrm{As}, \mathrm{Cd}$ and $\mathrm{Pb}$ contents were estimated on dry weight basis and expressed as $\mu \mathrm{g}$ metal / $\mathrm{g}$ of dried tissue. As bioavailability of these metals are more crucial a comparative in vitro assay of bioavailability of minerals in raw fish hydrolysates of 10 fish species from the above 15 was carried out. Sardinella melanura, Sardinella albella, Exocoetus volitans, Carnax spp., Stolephorus commersoni, Anchovy commersonii, Selar spp. and Leiognathus spp. were used for the studies with boiled fish. Cooking methods including steaming, pressure cooking, boiling, frying and drying were applied to $S$. melanura and Amblygaster spp. in order to determine the effect of cooking on in vitro bioavailability of metals. The effect of digestion time on metal released was investigated by subjecting the samples to digestion at different times. The levels of $\mathrm{Fe}, \mathrm{Zn}, \mathrm{Cu}, \mathrm{Br}, \mathrm{Mn}, \mathrm{Cr}, \mathrm{K}, \mathrm{Ca}, \mathrm{Na}, \mathrm{Mg}, \mathrm{Cl}, \mathrm{Rb}, \mathrm{Sr}, \mathrm{Ti}, \mathrm{Ni}$, $\mathrm{Cd}$, and $\mathrm{Pb}$ in raw fish were 2.1- 11.08, $0.9-275,0.2-9.33,0.3-30.1,0.6-28.7,0.0-2.1$, 578.3 - 13553, 11.9- 80516.2, 12879- 71502, $28493-171429,98.3-24902.4,0.1-2.8$, 0.2- 232.4, 3.0-41. 8, $4.4-7.4,0.0-1.9$ and $0.7-10.7 \mu \mathrm{g} / \mathrm{g}$ respectively. $\mathrm{Hg}$ and As were not detected. The in vitro metal availability of raw fish hydrolysates was found to be lower than of that of the fish flesh.
\end{abstract}


The percentage of in vitro Fe availability in boiled S. melanura, Carnax, S. albella and $E$. volitans, A. commersonii, Selar spp, Leiognathus spp and in S. commersoni were $20 \%$, $36 \%, 23 \%$ and $28 \% 55 \%, 55 \%, 42 \%$ and $40 \%$ respectively. In $S$. melanura and Amblygaster spp. the metal contents were $(\mathrm{p}<0.05)$ found to be increased than raw fish with cooking except in few instances. Amblygaster spp. subjected to boiling, steaming and pressure cooking had higher percentages of in vitro $\mathrm{Fe}, \mathrm{Zn}, \mathrm{Cu}, \mathrm{Mg}, \mathrm{Na}$ and $\mathrm{Pb}$ availability compared with $S$. melanura. The percentages of the above metals ranged from $51-75 \%$, $13-27 \%, 47-91 \%, 44-59 \%, 62-70 \%, 9-60 \%$ respectively. The highest mean in vitro available Fe content, the highest in vitro available Fe percentage (77\%) and the highest in vitro available $\mathrm{Cu}$ percentage $(73 \%)$ were observed in the boiled fish. Drying of fish increased the in vitro available $\mathrm{Pb}, \mathrm{Na}$ and $\mathrm{Zn}$ percentage. Boiling of fish increased the in vitro available $\mathrm{Pb}, \mathrm{Mg}, \mathrm{Cu}$ and Fe percentage in $\mathrm{S}$. melanura. In Amblygaster spp. Fe, $\mathrm{Zn}$ and $\mathrm{Cu}$ decreased with drying at $65^{\circ} \mathrm{C}$. Frying of fish increased the in vitro available $\mathrm{Cu}$ percentage. Pressure cooking of fish increased the in vitro available $\mathrm{Fe}$ and $\mathrm{Zn}$ percentage. Drying at higher temperatures lowered the in vitro available $\mathrm{Fe}$ and $\mathrm{Zn}$ content and increased the $\mathrm{Pb}$ content of dried fish in both $S$. melanura and in Amblygaster sp. It can be concluded that boiling, steaming and pressure cooking are the best cooking methods for $S$. melanura and Amblygaster spp as far as they retain least amounts of heavy metals. The normal digestion time was found to be sufficient enough to provide in vitro available forms and the extended digestion time had not significant effect on the release of metals.

Therefore it can be concluded that fish studied can be a good source of nutritionally significant metals and these species contain within the permissible range of metals concerned. As cooking methods studied reduce toxicologically significant metals' in vitro bioavailability, these cooking methods can be considered to be effective. 